\title{
A Typical Agricultural Areas of China -Dezhou City's Land Use Structure Changes Based on Past Decade Data
}

\author{
Yuanzhi Wang \\ Geographic Department, Dezhou University, Dezhou, 253023, Shandong, China \\ Tel: 86-534-898-5841 E-mail: wangyuanzhi1@sina.com.cn
}

The research is financed by Shandong province office of education.No.S07WZ35

\begin{abstract}
Based on the statistical data of land-using in Dezhou City from 1996 to 2006, the changes of Dezhou City's land-using structures is described. Through the use of land-use change intensity index, land-use type of dynamic index, the contribution rate of changes, Land-use integrated index, the changes of Dezhou City's land-using structures is described is studied. The study is on quantity changes, velocity changes, as well as degree changes. Results showed that the change of cultivated land was not significant; scales of urban construction land, traffic land, and forest land were further increased; scale of unused land was reduced fast; and the difference of land use structure in each county of Dezhou City was evident. Land use changes in Dezhou city were driven by natural, economic and social factors. Finally, the causes of land use structure changes were analyzed and some suggestions were put forward.
\end{abstract}

Keywords: land use structure, typical agricultural areas, Dezhou City

\section{General situation of Dezhou City}

Dezhou City is located at latitude $36^{\circ} 24^{\prime}-38^{\circ} 00$ ', longitude $115^{\circ} 45^{\prime}-117^{\circ} 24^{\prime}$ in the north-west of Shandong Province, at the junction of Shandong and Hebei, at the lower reaches of the north shore Yellow River, in the North China platform on Depression part of the Bohai Sea. In Dezhou territory, the Yellow River had two great migrations, thousands of sub-bursts, creating the Southwest High, Northeast low, undulating plains. Dezhou City includes Decheng Zone, Laoling City, Yucheng City, Ling County, Pingyuan County, Xiajin County, Wucheng County, Qihe County, Linyi County, Ningjin County, Qingyun County. Dezhou City is semi-humid continental monsoon climate, significantly affected by the monsoon. Its character is four distinct seasons, hot-cold and wet-dry boundaries clear. The dezhou region's major natural disasters are droughts, floods, dry-hot wind, and hail. The main soil types are Chao soil, accounting for $96 \%$; others are a small amount of salt solonchak and aeolian sandy soil. As the reclamation has a long history, natural forests and grasslands crossing type of vegetation, has been replaced by crops vast majorityly. Dezhou City is an important grain, cotton, vegetable production base of China. In 2006, the total population is about $5.49 \times 10^{6}$; the total land area is $1.04 \times 10^{6} \mathrm{hm}^{2}$.

\section{Data sources}

The data is from Dezhou Statistics Yearbook 1997-2007. With Standard Land Use Classification of the State Agriculture Zoning Commission in 1984 published, land-use types of study area are divided into cultivated land, forest land, garden Land, grassland, residents and industrial and mining land use, transportation land, water (including water Land surface and conservancy) and non-use of land.

\section{Quantitative methods}

Change intensity index is a percentage that an area of land-use change is divided by the total land area in the study period. It can be used to compare the strength of land-use change or potential trend. The formula is:

$$
T_{i}=\frac{U_{b i}-U_{a i}}{B},(i=1,2, \ldots 8)
$$

Where, $T_{i}$ denotes the intensity of the i'th land-use type changes in study period; $U_{a i}$ denotes the i'th land-use type area at the beginning; $U_{b i}$ denotes the $\mathrm{i}$ 'th land-use type area at the ending; $B$ denotes the the total area of the study area at the ending.

Land-use type of dynamic index is the rate of change for a certain type land-use in the study area within a certain time. Its calculation formula is: 


$$
K_{i}=\frac{U_{b i}-U_{a i}}{U_{a i}} \times \frac{1}{T} \times 100 \%,(i=1,2, \ldots 8)
$$

Where, $K_{i}$ denotes dynamic index for a certain land-use types within study period; $U_{a i}$ denotes the i'th land-use type area at the beginning; $U_{b i}$ denotes the i'th land-use type area at the ending; $T$ denotes the study period.

The contribution rate of changes is the percentage that the certain type land-use change contributes to the total Land-use change in the same period. The formula is:

$$
A_{i}=\frac{U_{b i}-U_{a i}}{\sum\left(U_{b i}-U_{a i}\right)}
$$

Where, $A_{i}$ denotes the contribution rate of changes of the i'th land-use type within Study period; $U_{a i}$ denotes the i'th land-use type area at the beginning; $U_{b i}$ denotes the i'th land-use type area at the ending.

The formula of Land-use integrated index is:

$$
L_{d}=100 \times \sum_{i=1}^{4} A_{i} \times C_{i}, L_{d} \in(100,400)
$$

Where, $L_{d}$ denotes Land-use integrated index; $A_{i}$ denotes the percentage of the i'th level land-use; $C_{i}$ denotes the level of land-use. $C_{i}$ is listed in table1. Land-use integrated index reflecting regional land use in the breadth and depth, which not only reflects the land use of their natural attributes, but also reflects the human factors of the land system.

\section{Results and analysis}

\subsection{Quantity of land-use change in Dezhou}

Quantity of land-use change is mainly reflected in the area. As can be seen in table 2: 1996-2006 years, woodland, residential, industrial and mining land, transportation land are on the rise; Garden, water, grassland and unused land are decreasing. Area change is significant in residential, industrial and mining land, water, garden, and unused land.

\subsection{Land use structure changes of Dezhou}

In table 3, the change rate of cultivated land is $73.1 \mathrm{hm}^{2}$ every year; garden are- $252.4 \mathrm{hm}^{2}$ every year; woodland are $87.6 \mathrm{hm}^{2}$; grassland are $-19 \mathrm{hm}^{2}$; water area are $-861.5 \mathrm{hm}^{2}$; residential, industrial and mining land are 1101.4 $\mathrm{hm}^{2}$; transport land are $48.6 \mathrm{hm}^{2}$; unused land are - 194. $9 \mathrm{hm}^{2}$. In 1996-2006, Residential, industrial and mining land, transportation land, woodland show a rising trend, while gardens, Grassland and unused land are decreasing. Residential, industrial and mining land use, transportation and Woodland make a greater contribution to land-use change.

\subsection{Change of land use extent}

From table 5, as time goes on, land-use integrated index shows a gradual increase. It shows that the breadth and depth of Dezhou land use is a gradual increase in over the last decade. Especially since 2002, due to land increase of the residents and the industrial and mining sites and traffic, Land-use integrated index increase rapidly.

\subsection{Land use structure changes of each Dezhou county}

In table4, Laoling City, Yucheng City, Qihe County and Qinyun County have a decrease in cultivated land, and others have have a slight increase; Only Laoling City, Qinyun County have increased for garden land, and all others have decreased; Decheng Zone, Laoling City, and Xiajin County have a larger increase for woodland, and other counties have been reduced; All counties have general decline in water and grassland; Except Decheng Zone, the other has increased for transport land; residential, industrial and mining land have increasing trend in all counties; Except Yucheng City and Qihe County, others have a reduction for unused land.

\subsection{Driving forces of land use structure change}

Regional land use structure change is driven by natural, economic and social aspects. The natural factors are long-term factors to land use structure. Economic and social factors more affect land use structure in the short time.

The Dezhou's soil is mainly alkaline Chao soil. Soil fertility is low and the structure is poor. Influenced by the semi-humid monsoon climate, drought, water logging, alkaline are frequent natural disasters and ecological environment is uncertain. To maintain a certain cultivated land area is the base of the economic sustained and 
steady development for an agricultural city.

Population growth is continuous external pressure force for land use change. The population of Dezhou has increased by $3.9 \times 10^{6}$ from 1996-2006. The cultivated land has increased by only $7.3 \times 10^{3} \mathrm{hm}^{2}$ through land improvement in recent years. As the population increases, residents and transport would add new pressures to unused the land.

From an economic development perspective, economic growth will drive consumer demand, and stimulate people to adjust the existing land use structure. As the economy development, in past ten years, residential, transportation land, woodland has increased; transport land increased rapidly in the early 90s in the 20th century; gardens, grassland and waters decreased significantly affected by the market in recent years.

Land management policy, the government development awareness and investment policies have a very significant impact on the land use method. Since the provincial level economic development zone is legislated in Dezhou in 1992, urban population is accreted; urban area, municipal construction and other public land area is expanded constantly; various industrial parks, small commodity city, commercial areas, residential land area is ever-increasing.

\section{Conclusion and suggestion}

By using change intensity index, land-use type of dynamic index, contribution rate of changes and Land-use integrated index, temporal and spatial land use changes is analyzed, and driving force of land use structure is explored. It has a certain reference value on the spatial and temporal evolution of land use laws.

From 1996 to 2006, cultivated land has little change; urban construction land, transportation land and woodland continues to increase; unused land area is reduced quickly. Such structure change is different in the different counties due to the regional natural, economic and social factors.

The above two points are conclusions. The following three points are the proposals.

Land use planning should be fully integrated consideration of natural, economic, social and other factors. Reasonable arrangements for the number of various types of land use and spatial layout put land to rational use in time and space.

Priority should be given to protect agricultural land. In ensuring the realization of agricultural land under the premise of dynamic equilibrium, the relationship between agricultural and non-agricultural land should be well-coordinated. At the same time, it is necessary for focusing on ecological construction, and improving economic, social and ecological benefits of land use in the land-use process.

Non-agricultural construction land should be controlled; farmland compensation system should be built in order to curb the momentum of further reduction of cultivated land to maintain the dynamic balance of the total cultivated land.

\section{References}

Luo, Zhenli. (2005). Study on Regional Agricultural Structure Adjustment under Sustainable Background. Changsha: Hunan People's Publishing House, pp.157-173.

Luo, Zhenli. (2006). Discuss on the management of sustainable utilization of regional land resource from virtual land angle. Land Resources Herald, 3(2), 17-20.

Zhu Huiyi, Li Xiubin. (2003). Discussion on the Index Method of Regional Land Use Change. Acta Geographica Sinica, 58(5), 643-648.

Wang Qun, Wang Wan-mao. (2005). Case Study on Driving Forces of Land Use Difference at Provincial Level in China. China Land Science, 19(6), 22-25

Table 1. Assignment of the level of land-use

\begin{tabular}{|l|l|l|l|l|}
\hline $\begin{array}{l}\text { Level of } \\
\text { land-use }\end{array}$ & Unused land & Forest|grass $\mid$ water & Agricultural land & Construction and settlement land \\
\hline Description & $\begin{array}{l}\text { Unused } \\
\text { or difficult } \\
\text { to use }\end{array}$ & $\begin{array}{l}\text { Woodland, grassland, } \\
\text { water area }\end{array}$ & $\begin{array}{l}\text { cultivated land, garden, } \\
\text { artificial turf }\end{array}$ & $\begin{array}{l}\text { Construction, residential, } \\
\text { industrial and mining land }\end{array}$ \\
\hline assignment & 1 & 2 & 3 & 4 \\
\hline
\end{tabular}


Table 2. Each type land use change from 1996 to 2006(unites $10^{4} \mathrm{hm}^{2}$ )

\begin{tabular}{|l|l|l|l|l|l|l|l|l|l|}
\hline Year & $\begin{array}{l}\text { Cultivated } \\
\text { land }\end{array}$ & Garden & Woodland & Grassland & $\begin{array}{l}\text { Water } \\
\text { area }\end{array}$ & $\begin{array}{l}\text { Residential, } \\
\text { industrial } \\
\text { and mining } \\
\text { land }\end{array}$ & $\begin{array}{l}\text { Transport } \\
\text { land }\end{array}$ & $\begin{array}{l}\text { Unused } \\
\text { land }\end{array}$ & Total \\
\hline 1996 & 62.641 & 5.082 & 2.298 & 0.021 & 11.478 & 13.444 & 2.935 & 5.661 & 103.56 \\
\hline 2000 & 62.791 & 5.533 & 2.486 & 0.026 & 10.896 & 13.511 & 3.038 & 5.279 & 103.56 \\
\hline 2004 & 61.858 & 4.493 & 3.163 & 0.030 & 11.170 & 14.240 & 3.384 & 5.222 & 103.56 \\
\hline 2006 & 63.372 & 2.558 & 3.174 & 0.002 & 2.863 & 14.458 & 3.421 & 3.712 & 103.56 \\
\hline
\end{tabular}

Table 3. Indexes of Dezhou City's Land use Structure Changes

\begin{tabular}{|c|c|c|c|c|c|}
\hline Types & index & $1996-2000$ & $2000-2004$ & $2004-2006$ & 1996-2006 \\
\hline \multirow{4}{*}{$\begin{array}{l}\text { cultivated } \\
\text { land }\end{array}$} & Area changes $(\mathrm{hm} 2)$ & 15007310 & -9330 & 15140 & 7310 \\
\hline & Change intensity index $(\%)$ & 0.145 & 0.901 & 1.462 & 0.706 \\
\hline & dynamic index $(\%)$ & 0.024 & -0.149 & 0.2448 & 0.1167 \\
\hline & contribution rate of changes $(\%)$ & 7.808 & 22.980 & 0.975 & 2.789 \\
\hline \multirow{4}{*}{ Garden } & Area changes $(\mathrm{hm} 2)$ & 4510 & -10400 & -19350 & -25240 \\
\hline & Change intensity index $(\%)$ & 0.435 & 1.004 & 1.869 & 2.437 \\
\hline & dynamic index $(\%)$ & 0.887 & -1.880 & -4.307 & -4.967 \\
\hline & contribution rate of changes $(\%)$ & 23.390 & 25.620 & 1.087 & 9.628 \\
\hline \multirow{4}{*}{ Woodland } & Area changes $(\mathrm{hm} 2)$ & 1880 & 6770 & 1108 & 760 \\
\hline & Change intensity index $(\%)$ & 0.182 & 0.654 & 0.011 & 0.846 \\
\hline & dynamic index $(\%)$ & 0.818 & 2.723 & 0.035 & 3.812 \\
\hline & contribution rate of changes $(\%)$ & 9.751 & 16.670 & 0.708 & 3.342 \\
\hline \multirow{4}{*}{ Grassland } & Area changes $(\mathrm{hm} 2)$ & 50 & 40 & -280 & -190 \\
\hline & Change intensity index $(\%)$ & 0.005 & 0.004 & 0.027 & 0.018 \\
\hline & dynamic index $(\%)$ & 2.381 & 1.538 & -9.330 & -9.050 \\
\hline & contribution rate of changes $(\%)$ & 0.259 & 0.099 & 0.004 & 0.073 \\
\hline \multirow{4}{*}{ Water area } & Area changes $(\mathrm{hm} 2)$ & -5820 & 2740 & -83070 & -86150 \\
\hline & Change intensity index $(\%)$ & 0.562 & 0.265 & 8.021 & 8.31 \\
\hline & dynamic index $(\%)$ & -0.510 & 0.251 & -7.440 & -7.510 \\
\hline & contribution rate of changes $(\%)$ & 30.190 & 6.749 & 0.286 & 32.860 \\
\hline \multirow{4}{*}{$\begin{array}{l}\text { Residential, } \\
\text { industrial and } \\
\text { mining land }\end{array}$} & Area changes $(\mathrm{hm} 2)$ & 670 & 7290 & 102180 & 110140 \\
\hline & Change intensity index $(\%)$ & 0.065 & 0.704 & 9.867 & 10.640 \\
\hline & dynamic index $(\%)$ & 0.050 & 0.540 & 7. 176 & 8.193 \\
\hline & contribution rate of changes $(\%)$ & 3.475 & 17.960 & 0.762 & 42.020 \\
\hline \multirow{4}{*}{$\begin{array}{l}\text { Transport } \\
\text { land }\end{array}$} & Area changes $(\mathrm{hm} 2)$ & 1030 & 3460 & 3704 & 860 \\
\hline & Change intensity index $(\%)$ & 0.099 & 0.334 & 0.036 & 0.469 \\
\hline & dynamic index $(\%)$ & 0.351 & 1.139 & 0.109 & 1.656 \\
\hline & contribution rate of changes $(\%)$ & 5.342 & 8.522 & 0.362 & 1.854 \\
\hline \multirow{4}{*}{ Unused land } & Area changes $(\mathrm{hm} 2)$ & -3820 & -570 & -15100 & -19490 \\
\hline & Change intensity index $(\%)$ & 0.369 & 0.055 & 1.458 & 1.882 \\
\hline & dynamic index $(\%)$ & -0.670 & -0.108 & -2.892 & -3.443 \\
\hline & contribution rate of changes $(\%)$ & 19.810 & 1.404 & 0.060 & 7.435 \\
\hline
\end{tabular}


Table 4. Dynamic index for each counties years of Dezhou 1996-2004

\begin{tabular}{|c|c|c|c|c|c|c|c|c|c|c|c|c|}
\hline & $\begin{array}{l}\text { Dezhou } \\
\text { city }\end{array}$ & $\begin{array}{l}\text { Decheng } \\
\text { Zone }\end{array}$ & $\begin{array}{l}\text { Laoling } \\
\text { City }\end{array}$ & $\begin{array}{l}\text { Yucheng } \\
\text { City }\end{array}$ & $\begin{array}{l}\text { Ling } \\
\text { County }\end{array}$ & $\begin{array}{l}\text { Pingyuan } \\
\text { County }\end{array}$ & $\begin{array}{l}\text { Xiajin } \\
\text { County }\end{array}$ & $\begin{array}{l}\text { Wucheng } \\
\text { County }\end{array}$ & $\begin{array}{l}\text { Qihe } \\
\text { county }\end{array}$ & $\begin{array}{l}\text { Linyi } \\
\text { County }\end{array}$ & $\begin{array}{l}\text { Ningjin } \\
\text { County }\end{array}$ & $\begin{array}{l}\text { Qinyun } \\
\text { County }\end{array}$ \\
\hline $\begin{array}{l}\text { Cultivated } \\
\text { land }\end{array}$ & 0.12 & 0.46 & -0.32 & -0.52 & 1. 15 & 0.85 & 0.27 & 0.46 & -0.8 & 0.14 & 0.14 & -0.34 \\
\hline Garden & -4.97 & -5.81 & 7. 16 & -9.25 & -8.22 & -8.99 & -4.35 & -9.17 & -8.45 & -7.61 & -6.34 & 5.81 \\
\hline Woodland & 1. 13 & 17.79 & 117.60 & -8.88 & -6.51 & -6.25 & 2.84 & -7.43 & -7.69 & -9.10 & -1.90 & 171.80 \\
\hline Grassland & -9.91 & -10.00 & -10.00 & -10.00 & -7.16 & -10.00 & -10.00 & -10.00 & 0.00 & -10.00 & -10.00 & -10.00 \\
\hline Water area & -7.52 & -7.29 & -6.11 & -7.66 & -7.12 & -7.21 & -7.91 & -8.31 & -7.73 & -8.07 & -8.95 & -6.93 \\
\hline $\begin{array}{l}\text { Residential, } \\
\text { industrial } \\
\text { and mining } \\
\text { land }\end{array}$ & 8.20 & 9.38 & 7.69 & 10.10 & 6.35 & 9.25 & 7. 73 & 8. 30 & 9.58 & 6.95 & 5.04 & 11.07 \\
\hline $\begin{array}{l}\text { Transport } \\
\text { land }\end{array}$ & 1. 65 & -0.78 & -1.28 & 2.58 & 0.68 & 3.30 & 1. 29 & 1.80 & 3.78 & 2.54 & 1. 48 & 2.65 \\
\hline $\begin{array}{l}\text { Unused } \\
\text { land }\end{array}$ & -3.44 & -7.65 & -5.84 & 0.25 & -4.08 & -5.26 & -3.45 & -4.41 & 4. 85 & -2.02 & -1.29 & -4.53 \\
\hline
\end{tabular}

Table 5. Land-use integrated index from 1996 to 2006

\begin{tabular}{|l|l|l|l|l|l|l|l|l|l|l|l|}
\hline year & 1996 & 1997 & 1998 & 1999 & 2000 & 2001 & 2002 & 2003 & 2004 & 2005 & 2006 \\
\hline $\begin{array}{l}\text { integrated } \\
\text { index }\end{array}$ & 293.11 & 291.03 & 293.52 & 291.38 & 292.68 & 291.75 & 292.53 & 292.89 & 293.70 & 310.72 & 313.70 \\
\hline
\end{tabular}

